\title{
CENTRALISED OR DECENTRALISED PUBLIC FINANCING OF CLUSTERS
}

\author{
Nataša URBANČÍKOVÁ ${ }^{1}$, Peter BURGER ${ }^{2}$ \\ Department of Regional Sciences and Management, Faculty of Economics, \\ Technical University of Košice, Němcovej 32, 04001 Košice, Slovak Republic \\ E-mails: ${ }^{n}$ atasa.urbancikova@tuke.sk (correspondingauthor); ${ }^{2}$ peter.burger@tuke.sk
}

Received 20 June 2013; accepted 27 August 2013

\begin{abstract}
The public funds have become a major source of finance for clusters in the last decade, also in European countries. The source of financing clusters and innovation performance of the countries is directly connected to subjects of the national/regional cluster policy, i.e. to its centralisation. The paper examines the relationship between European country attitude towards financial support provided for cluster and country innovative performance in a sample of 125 clusters from 25 European countries. The own empirical investigation is based on primary research using the Kruskal-Wallis test and Mann-Whitney tests with Bonferroni. The investigation is focused on facts whether statistically significant differences in the amount of subsidies from national, regional, local and "European" levels between clusters in European countries influence their level of innovation performance. The finding shows that there are no statistically significant differences in the exploitation of resources from the Structural Funds and community programmes of the EU in the examined clusters in the countries with different levels of innovation performance. However, the clusters in the countries with higher levels of innovation performance receive funds in the form of central government and regional self-government subsidies more frequently than the clusters in the countries with lower levels of innovation performance.
\end{abstract}

Keywords: clusters, cluster policies, financing clusters, public funds, innovation performance, European countries.

JEL Classification: O31, O38, R58.

\section{Introduction}

According to a number of studies, public funds have become a major source of finance for clusters in the last decade, in the European countries in particular; however, also in Japan, South Korea or the USA (Barsoumian et al. 2011; Meier zu Köcker 2009; Oxford Research AS 2008; Borrás, Tsagdis 2008; OECD 2007; Sölvell et al. 2003). The approach of European countries towards financial support provided for clusters and towards the amount of such support varies from country to country. Besides, the countries tend to perceive differently where the support to clusters should come from - whether from the national or regional/local public sources, or possibly from the Structural Funds 
and community programmes of the European Union. Therefore the main objective of the article is to study differences in amount of subsidies from national, regional, local and "European" levels between clusters in European countries and to investigate, whether the financing of clusters from the closer territorial level (regional, national) is in a positive relation to country innovation performance.

\section{Theoretical framework and previous empirical findings}

The respected measure for a country's innovation performance is provided by the Summary Innovation Index (European Commission 2013) reflecting the input and output indicators of research, development, innovation, entrepreneurship and intellectual property. Clusters as a geographic concentration of interconnected companies and institutions have become an important object of the innovation policy financial interventions (Ketels 2015; Uyarra, Ramlogan 2012). Two processes forming the extent of cluster policy regionalisation are in progress in Europe nowadays: the downward decentralising process and a parallel process aiming at higher internationalisation and international cooperation (Borrás, Tsagdis 2008). The greater extent of internationalisation and international cooperation is frequently viewed as a key element of cluster policy and clusters are regarded as an effective tool for promoting international cooperation, productivity and innovation - all these are closely related to growing competitiveness of national and international markets.

Cluster policy follows present global development trends towards strengthening the decentralisation of power and responsibility to lower state and public administration levels and the authority of regional and local institutions (Kaklauskas et al. 2009). The extent of centralisation may significantly influence the dynamics of cluster processes in a country. In countries with a higher centralisation of public institutions including their decision-making authority, the national level of cluster support dominates over the regional or local ones. Nonetheless, a cluster policy always requires at least partial decentralisation of the decision-making processes. In most cases the level of centralisation is affected by the concentration of funds at the national level (Andersson et al. 2004). The role of national government is still fundamental to many economies. A centralised cluster policy effort is aimed at gaining a competitive advantage at a local or regional level; however, with the central coordination of processes from the government. Funds are also allocated almost entirely from the national level. One of the common forms of intervention at the governmental level is financial aid provided to the private sector in the form of state subsidies. France and Norway are held up as instances of a centralised cluster policy in Europe.

A decentralised cluster policy is typical for regions with the strong awareness of a regional identity shared by the regional government and its citizens. Therefore, the cluster policy is a part of the broader process of decentralisation of regional policy. Decentralised cluster policies are typical in the case of regions in Austria, Italy and Spain. A cluster feedback policy is a mixed policy that is pursued across different levels of country management. Mostly, it is the national level that creates the basic framework for 
a cluster policy in a country and enables the lower levels to initiate, create and implement individual cluster policies. Sweden and the UK are typical examples of the cluster feedback policy implementation (Raines 2001).

Belgium belongs to the countries with the most decentralised cluster policy in Europe, where each of the three regions follows its own cluster policy, whereas there is no cluster policy at national level. On the contrary, a country with a high centralisation of cluster policies at the national level is France. The cluster policy has been pursued at the regional level since the beginning of the 1990's and since 2006 there has also been implemented a national cluster policy. Some other countries, such as Netherlands, have established a national cluster policy framework but with regional authorities assisting partially in the policy implementation (Barsoumian et al. 2011). The system applied in the Netherlands corresponds partly to a cluster support strategy that relies on centralisation and coordination of cluster programmes at the national level if it is ensured that the process support takes place at the lower levels. To foster the development of clusters, funds should be allocated from a local level without the necessity of constantly requiring the approval of the national authorities (Andersson et al. 2004).

Many of empirical studies have dealt with regionalisation of cluster policies in the last five years (Barsoumian et al. 2011; Meier zu Köcker 2009; Oxford Research AS 2008; OECD 2007). Ireland, Israel, Norway and Portugal are the countries attaching greater importance to national policies; unlike Austria, Belgium, Denmark, Italy and Spain (Oxford Research AS 2008). According to another study, a cluster policy is implemented primarily at the national level in most European countries (Bulgaria, the Czech Republic, Estonia, Finland, France, Greece, Hungary, Ireland, Latvia, Lithuania, Luxemburg, Malta, The Netherlands, Portugal, Romania and Slovenia). The regional level in supporting cluster policies dominates only in Austria, Belgium and Denmark (Barsoumian et al. 2011). At the same time, all the mentioned studies point to the high amount of support offered to cluster policies, evenly distributed between the national and regional levels in the countries with a high level of innovation performance, such as Germany, Sweden and Great Britain. Several studies also agree on a shortage of public funds for clusters operating in the countries with lower levels of innovation performance through national, regional or local subsidies (Oxford Research AS 2008; OECD 2007; Ketels et al. 2006; CLOE 2006).

Many of the countries try to make up this deficit by raising funds from the Structural Funds and community programmes of the European Union. European funds as a regional development policy tool focus on reducing regional disparities between the wealthiest and poorest EU member countries and regions. Less developed countries and regions also show lower levels of innovation performance (Ginevičius, Podvezko 2009). The clusters in the countries with higher levels of innovation performance are eligible to receive subsidies for their activities from the national and/or regional public sources. However, countries with lower levels of innovation performance (Poland, Hungary and Bulgaria) regard the Structural Funds as an essential financial source for cluster innovation and research and development (Urbančíková, Burger 2010; Bialic- 
Davendra, Pavelková 2011). Similarly, the Structural Funds play a significant role in cluster support in the Czech Republic (Skokan, Zotyková 2014; Ministry of Industry and Commerce of the Czech Republic 2010), Slovakia (Ministry of Economy of the Slovak Republic 2011) and Lithuania.

\section{Methodology and hypotheses}

The own empirical investigation is based on extensive primary research. A survey was carried out during the years 2011 and 2012. In total 834 clusters from the European countries were addressed and a total of 125 cluster representatives properly responded to the questionnaires. The overall response rate was $14.99 \%$. Primarily the facilitators of the clusters were interviewed. The majority of responses were received from the cluster representatives in the Czech Republic (17), Germany and Slovakia (14), Hungary (12), Sweden (8), Denmark (7) and Spain (6). Four responses came from the cluster representatives in Austria, Italy, Norway, Poland, Romania, Switzerland and the UK respectively. Three responses were obtained from Netherlands and Lithuania and the other European countries delivered only maximum two responses.

Public funds for clusters may be allocated from different government levels. The recent research studies (Rothgang et al. 2015; Lindqvist, Sölvell 2011; Barsoumian et al. 2011; Sölvell 2009; Pavelková et al. 2009) have served as the basis for the creation of a suitable method of classifying cluster financing within the system of public funds as follows:

1. National budgets (national/governmental funds to finance cluster activities);

2. Regional budgets (regional funds to finance cluster activities);

3. Local budgets (municipal funds to support cluster activities);

4. European Union budgets (funding cluster activities from the EU funds).

The same options for answers have been used in the survey. The cluster managers were asked to mark the approximate structure of the income part of the cluster annual budget from the external sources. The aim of the article is then to investigate statistically significant differences in the amount of subsidies from national, regional, local and "European" levels between clusters in European countries; and if shares of the various forms of subsidies in clusters' budgets differ according to country innovation performance. The theoretical framework and previous empirical studies analysed lead to testing the following hypotheses:

H1: Clusters in the countries with higher levels of innovation performance have a larger share of national and regional subsidies in their budgets than those in the countries with lower levels of innovation performance.

H2: Clusters in the countries with lower levels of innovation performance have a larger share of the Structural Funds and community programmes of the European Union in their budgets, than those in the countries with higher levels of innovation performance.

The former hypotheses require a certain classification system to determine the innovation performance of a particular country. The source used for such determination/ 
evaluation is the Innovation Union Scoreboard 2013 and the main classification tool known as the Summary Innovation Index (European Commission 2013). With respect to this index, European countries are divided into four groups- innovation leaders (Sweden, Germany, Denmark and Finland), innovation followers (Netherlands, Luxembourg, Belgium, the UK, Austria, Ireland, France, Slovenia, Cyprus and Estonia), moderate innovators (Italy, Spain, Portugal, Czech Republic, Greece, Slovakia, Hungary, Malta and Lithuania) and modest innovators (Poland, Latvia, Romania and Bulgaria). In comparison to the previous year evaluation, only two changes in 'EU Member States' innovation performance" occurred. Lithuania advanced to the group of moderate innovators and Poland moved down becoming a modest innovator. It should be however noted, that the change in performance group was due to marginal changes of the innovation performance in both cases. In this research, the first two groups (innovation leaders, innovation followers) are considered to be the countries with a higher level of innovation performance, the third and fourth groups (moderate innovators, modest innovators) are defined as the countries with a lower level of innovation performance. In both selected samples, there are a sufficient number of statistical units -51 clusters $(40.80 \%)$ with a higher level and 74 clusters $(59.20 \%)$ with a lower level of innovation performance what makes the independent samples representative and thus enables the generalizations of the statements via hypothesis testing.

The empirical research leads to testing the clusters with different innovation performance using Kruskal-Wallis test and pair comparisons using Mann-Whitney tests with Bonferroni correction to determine whether the equality of the share of public funds in various groups of countries is related to their innovation performance. The KruskalWallis test is considered as non-parametric alternative to the single-factor analysis of variance. It compares medians of more than two independent populations providing that the conditions for the use of classical parametric analysis of variance are not met. The Kruskal-Wallis test requires neither the fulfilment of the condition for statistical homogeneity of variance nor the normality of distribution. If the null hypothesis is rejected, there is a difference between at least of one the pairs of medians (Sheskin 2007; Hudec et al. 2007). After the rejection of the null hypothesis in the Kruskal-Wallis test, a post-hoc test is performed - the Mann-Whitney test with Bonferroni inequality correction. The Mann-Whitney U-test belongs to more powerful non-parametric tests. To minimise type II errors, the level of significance is corrected with Bonferroni correction (Monroe 2006).

\section{Allocation of public funds to cluster budgets}

The allocation of public funds to the budgets of clusters in the countries divided according to their level of innovation performance varies from one cluster group to another. The most balanced shares are seen in the clusters of innovation leader countries, as can be seen in Figure 1. Concerning the structure of funds, the Structural Funds and community programmes of the EU and subsidies from the central government are dominant in this group of clusters. Subsidies from local self-government present the lowest share. 
There is a high share of regional self-government subsidies in the budgets of innovation followers, as can be seen in Figure 2. This might be due to the presence of several Austrian clusters in the examined sample as regional self-government is one of the key driving forces in the Austrian cluster policy. On the contrary, the percentage share of subsidies from the central government is lower than in the case of clusters in the countries of innovation leaders.

As shown by the primary research results in Figure 3, it is possible to see the dominance of funds from the Structural Funds and community programmes of the EU in the cluster budgets in the countries of moderate innovators. There are minor differences between subsidies of various types - central state subsidies, regional and local self-government subsidies - when considering their shares in the cluster budgets.

When assessing the percentage of public funds in the cluster budgets in the countries of the modest innovators, it is necessary to take into account the low quantity of clus-

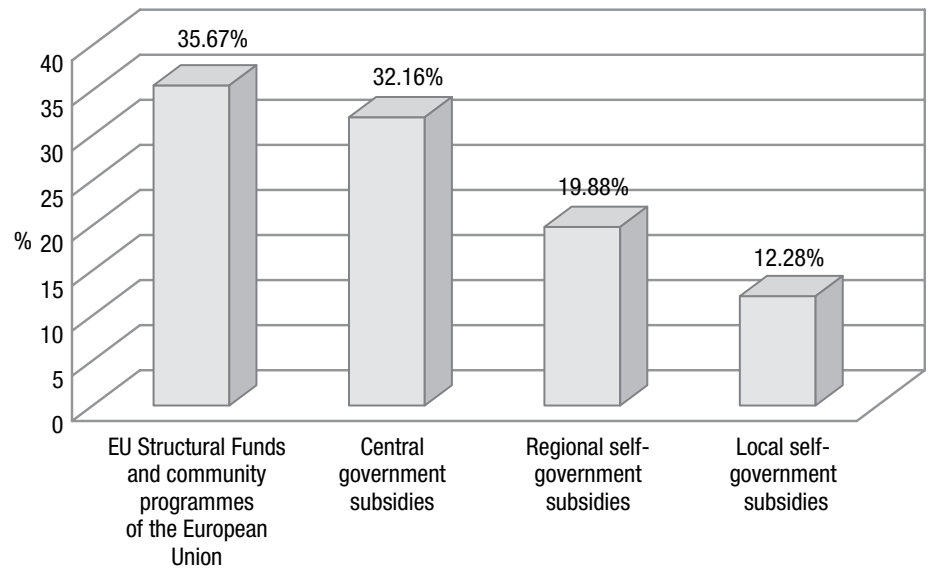

Fig. 1. Percentage of public funds shares in the cluster budgets in the countries of innovation leaders

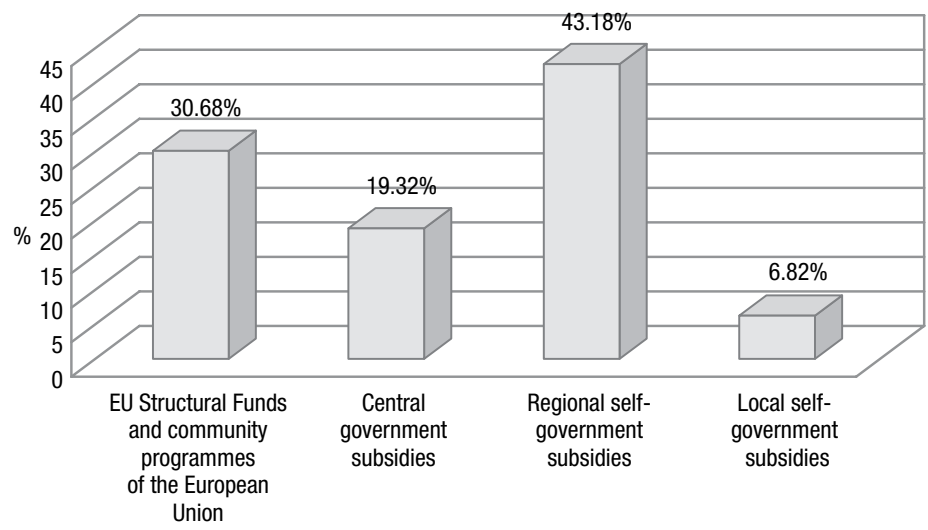

Fig. 2. Percentage of public funds in the cluster budgets in the countries of innovation followers 


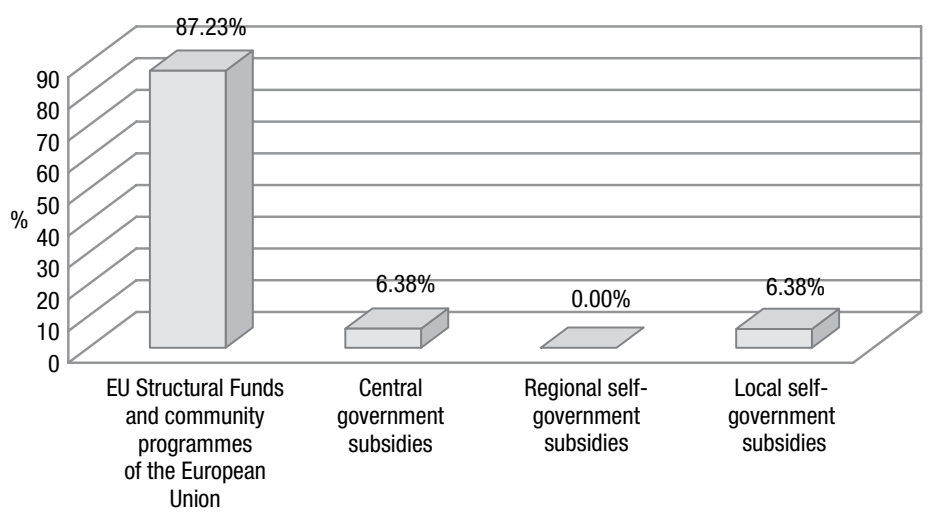

Fig. 3. Percentage of public funds in the cluster budgets in the countries of moderate innovators

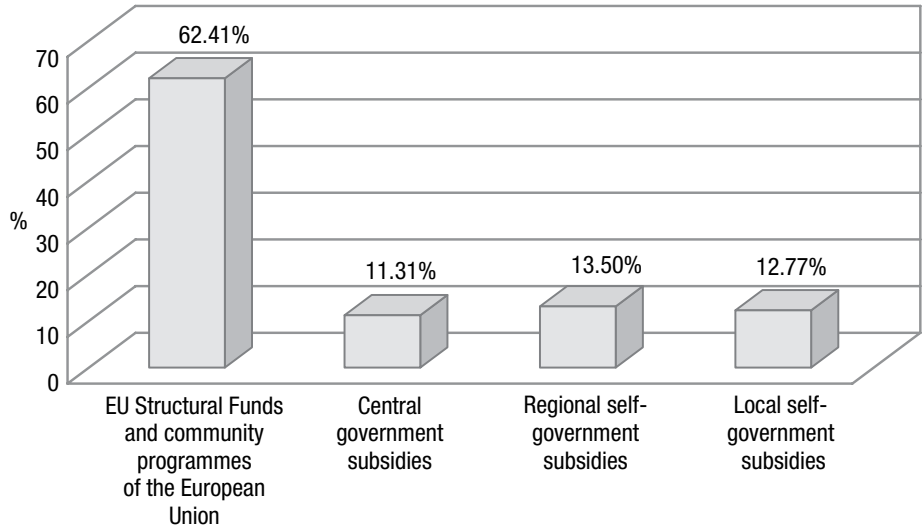

Fig. 4. Percentage of public funds in the cluster budgets in the countries of the modest innovators

ters responding to the survey in this group. In total there were eleven clusters in the group; however, even such a small sample proved that the clusters in the countries of the weakest innovators have rare opportunities to gain finance for their activities from the national, regional and local levels, as can be seen in Figure 4. They can raise public funds for their activities only when succeeding in gaining some resources from the Structural Funds and community programmes of the European Union.

\section{Comparison of shares of various kinds of public funds in cluster budgets}

When comparing the share of various kinds of public funds (Structural Funds and community programmes of the European Union, central government subsidies, and regional and local self-government subsidies) in cluster budgets, the presence of statistically significant differences between clusters operating in countries with different levels of innovation performance was detected. In the process of examination of the proposed 
hypotheses - whether the clusters in the countries with higher levels of innovation performance benefit from higher shares of national and regional subsidies in their budgets and vice versa, the clusters in the countries with lower levels of innovation performance benefit more from the resources allocated from the Structural Funds and community programmes of the EU - the following results were found and summarized in Table 1.

\section{Kruskal-Wallis test}

$$
\begin{aligned}
& \mathrm{H}_{0}: \mu_{1}=\mu_{2}=\mu_{3}=\mu_{4} \\
& \mathrm{H}_{1}: \text { non } \mathrm{H}_{0}
\end{aligned}
$$

Table 1. Comparison of shares of the Structural Funds and community programmes of the European Union, central government subsidies, regional self-government subsidies and local

\begin{tabular}{|c|c|c|c|c|c|}
\hline & $\begin{array}{l}\text { Division of clusters } \\
\text { according to the innovation } \\
\text { performance of the } \\
\text { countries where these } \\
\text { clusters exist }\end{array}$ & $\begin{array}{l}\text { Number } \\
\text { of clusters }\end{array}$ & $\begin{array}{c}\text { Average } \\
\text { rank }\end{array}$ & \multicolumn{2}{|c|}{$\begin{array}{l}\text { Minimum level } \\
\text { of significance for } \\
\text { the rejection of the } \\
\text { null hypothesis }\end{array}$} \\
\hline \multirow{5}{*}{$\begin{array}{l}\text { Comparison of } \\
\text { shares of the EU } \\
\text { Structural Funds } \\
\text { and community } \\
\text { programmes in } \\
\text { annual cluster } \\
\text { budgets }\end{array}$} & $\begin{array}{l}\text { Clusters in the countries } \\
\text { of innovation leaders }\end{array}$ & 34 & 57.04 & \multirow{5}{*}{$\mathrm{p}$-value } & \multirow{5}{*}{0.130} \\
\hline & $\begin{array}{l}\text { Clusters in the countries } \\
\text { of innovation followers }\end{array}$ & 17 & 54.26 & & \\
\hline & $\begin{array}{l}\text { Clusters in the countries } \\
\text { of moderate innovators }\end{array}$ & 63 & 65.25 & & \\
\hline & $\begin{array}{l}\text { Clusters in the countries } \\
\text { of the modest innovators }\end{array}$ & 11 & 82.05 & & \\
\hline & Total & 125 & & & \\
\hline
\end{tabular}
self-government subsidies in annual cluster budgets in various groups of countries

$0.130>0.05 \mathrm{H}_{0}$ is not rejected (the differences in comparing the shares of the Structural Funds and community programmes of the European Union in cluster budgets in various groups of countries are not statistically significant; therefore, it is not necessary to compare their pairs,

\begin{tabular}{|c|c|c|c|c|c|}
\hline \multirow{4}{*}{$\begin{array}{l}\text { Comparison of } \\
\text { shares of central } \\
\text { government } \\
\text { subsidies } \\
\text { (government, } \\
\text { ministries) in } \\
\text { annual cluster } \\
\text { budgets }\end{array}$} & $\begin{array}{c}\text { Clusters in the countries } \\
\text { of innovation leaders }\end{array}$ & 34 & 78.93 & \multirow{5}{*}{ p-value } & \multirow{5}{*}{0.000} \\
\hline & $\begin{array}{l}\text { Clusters in the countries } \\
\text { of innovation followers }\end{array}$ & 17 & 74.74 & & \\
\hline & $\begin{array}{l}\text { Clusters in the countries } \\
\text { of moderate innovators }\end{array}$ & 63 & 54.39 & & \\
\hline & $\begin{array}{l}\text { Clusters in the countries } \\
\text { of the modest innovators }\end{array}$ & 11 & 44.95 & & \\
\hline & Total & 125 & & & \\
\hline
\end{tabular}
i.e. to perform the Mann-Whitney paired-sample test with Bonferroni inequality correction)

$0.000<0.05 \mathrm{H}_{0}$ is rejected (the differences in comparing the shares of the central government subsidies in cluster budgets in various groups of countries are statistically significant; therefore, it is necessary to compare their pairs, i.e. to perform the Mann-Whitney paired-sample test with Bonferroni inequality correction) 


\begin{tabular}{|c|c|c|c|c|c|}
\hline & $\begin{array}{l}\text { Division of clusters } \\
\text { according to the innovation } \\
\text { performance of the } \\
\text { countries where these } \\
\text { clusters exist }\end{array}$ & $\begin{array}{l}\text { Number } \\
\text { of clusters }\end{array}$ & $\begin{array}{l}\text { Average } \\
\text { rank }\end{array}$ & \multicolumn{2}{|c|}{$\begin{array}{l}\text { Minimum level } \\
\text { of significance for } \\
\text { the rejection of the } \\
\text { null hypothesis }\end{array}$} \\
\hline \multirow{5}{*}{$\begin{array}{l}\text { Comparison } \\
\text { of shares of } \\
\text { regional self- } \\
\text { government } \\
\text { subsidies in } \\
\text { annual cluster } \\
\text { budgets }\end{array}$} & $\begin{array}{l}\text { Clusters in the countries of } \\
\text { innovation leaders }\end{array}$ & 34 & 62.57 & \multirow{5}{*}{ p-value } & \multirow{5}{*}{0.002} \\
\hline & $\begin{array}{l}\text { Clusters in the countries of } \\
\text { innovation followers }\end{array}$ & 17 & 85.35 & & \\
\hline & $\begin{array}{l}\text { Clusters in the countries of } \\
\text { moderate innovators }\end{array}$ & 63 & 60.33 & & \\
\hline & $\begin{array}{l}\text { Clusters in the countries of } \\
\text { the modest innovators }\end{array}$ & 11 & 44.00 & & \\
\hline & Total & 125 & & & \\
\hline
\end{tabular}

$0.002<0.05 \mathrm{H}_{0}$ is rejected (the differences in comparing the shares of the regional selfgovernment subsidies in cluster budgets in various groups of countries are statistically significant; therefore, it is necessary to compare their pairs, i.e. to perform the Mann-Whitney pairedsample test with Bonferroni inequality correction)

\begin{tabular}{|c|c|c|c|c|c|}
\hline \multirow{4}{*}{$\begin{array}{c}\text { Comparison of } \\
\text { shares of local } \\
\text { self-government } \\
\text { subsidies } \\
\text { (municipalities } \\
\text { and towns) in } \\
\text { annual cluster } \\
\text { budgets }\end{array}$} & $\begin{array}{c}\text { Clusters in the countries of } \\
\text { innovation leaders }\end{array}$ & 34 & 65.04 & \multirow{5}{*}{$\mathrm{p}$-value } & \multirow{5}{*}{0.084} \\
\hline & $\begin{array}{l}\text { Clusters in the countries of } \\
\text { innovation followers }\end{array}$ & 17 & 76.97 & & \\
\hline & $\begin{array}{l}\text { Clusters in the countries of } \\
\text { moderate innovators }\end{array}$ & 63 & 59.83 & & \\
\hline & $\begin{array}{l}\text { Clusters in the countries of } \\
\text { the modest innovators }\end{array}$ & 11 & 57.95 & & \\
\hline & Total & 125 & & & \\
\hline
\end{tabular}

$0.084>0.05 \mathrm{H}_{0}$ is not rejected (the differences in comparing the shares of local self-government subsidies (municipalities and towns) in cluster budgets in various groups of countries are not statistically significant; therefore, it is not necessary to compare their pairs, i.e. to perform the Mann-Whitney paired-sample test with Bonferroni inequality correction)

Source: Self-processed (based on the IBM SPSS Statistics outputs).

The Kruskal-Wallis test shows there is a greater share of resources from the Structural Funds and community programmes of the EU in the budgets of the clusters in the countries of the modest and moderate innovators. All groups of clusters, however, regardless of the innovation performance of the country of residence of the cluster, benefit from this kind of resource to a great extent. This accounts for the fact that when comparing the shares of the Structural Funds and community programmes of the EU in the cluster budgets, the differences between the individual groups of countries with varying levels of innovation performance are not statistically significant. 
When comparing the shares of various types of subsidies in the cluster budgets - central government subsidies or regional or local self-government subsidies, statistically significant differences were identified. Therefore, it was reasonable to compare their pairs, i.e. to determine the groups of countries between which statistically significant differences occur. Mann-Whitney tests with Bonferroni correction were used for pair comparisons. The results from the comparisons are shown in Table 2 and Table 3.

\section{Mann-Whitney tests with Bonferroni correction}

$$
\begin{aligned}
& \mathrm{H}_{0}: \mu_{1}=\mu_{2} \quad \mathrm{H}_{0}: \mu_{1}=\mu_{3} \quad \mathrm{H}_{0}: \mu_{1}=\mu_{4} \quad \mathrm{H}_{0}: \mu_{2}=\mu_{3} \quad \mathrm{H}_{0}: \mu_{2}=\mu_{4} \quad \mathrm{H}_{0}: \mu_{3}=\mu_{4} \\
& \mathrm{H}_{1}: \mu_{1} \neq \mu_{2} \quad \mathrm{H}_{1}: \mu_{1} \neq \mu_{3} \quad \mathrm{H}_{1}: \mu_{1} \neq \mu_{4} \quad \mathrm{H}_{1}: \mu_{2} \neq \mu_{3} \quad \mathrm{H}_{1}: \mu_{2} \neq \mu_{4} \quad \mathrm{H}_{1}: \mu_{3} \neq \mu_{4}
\end{aligned}
$$

Table 2. Pair comparisons of shares of central government subsidies (governments, ministries)

\begin{tabular}{|c|c|c|c|c|}
\hline $\begin{array}{c}\text { Division of clusters according } \\
\text { to the innovation performance } \\
\text { of the countries where these } \\
\text { clusters exist }\end{array}$ & $\begin{array}{l}\text { Number of } \\
\text { clusters }\end{array}$ & $\begin{array}{l}\text { Average } \\
\text { rank }\end{array}$ & \multicolumn{2}{|c|}{$\begin{array}{l}\text { Minimum level of } \\
\text { significance for the } \\
\text { rejection of the null } \\
\text { hypothesis }\end{array}$} \\
\hline $\begin{array}{l}\text { Clusters in the countries } \\
\text { of innovation leaders }\end{array}$ & 34 & 27.12 & \multirow{3}{*}{ p-value } & \multirow{3}{*}{0.431} \\
\hline $\begin{array}{l}\text { Clusters in the countries } \\
\text { of innovation followers }\end{array}$ & 17 & 23.76 & & \\
\hline Total & 51 & & & \\
\hline \multicolumn{5}{|c|}{$0.431>0.00833 \mathrm{H}_{0}$ is not rejected } \\
\hline $\begin{array}{l}\text { Clusters in the countries } \\
\text { of innovation leaders }\end{array}$ & 34 & 61.04 & \multirow{3}{*}{ p-value } & \multirow{3}{*}{0.000} \\
\hline $\begin{array}{l}\text { Clusters in the countries } \\
\text { of moderate innovators }\end{array}$ & 63 & 42.50 & & \\
\hline Total & 97 & & & \\
\hline \multicolumn{5}{|c|}{$0,000<0.00833 \mathrm{H}_{0}$ is rejected: significant difference } \\
\hline $\begin{array}{l}\text { Clusters in the countries } \\
\text { of innovation leaders }\end{array}$ & 34 & 25.76 & \multirow{3}{*}{ p-value } & \multirow{3}{*}{0.006} \\
\hline $\begin{array}{l}\text { Clusters in the countries of the } \\
\text { modest innovators }\end{array}$ & 11 & 14.45 & & \\
\hline Total & 45 & & & \\
\hline \multicolumn{5}{|c|}{$0.006<0.00833 \mathrm{H}_{0}$ is rejected: significant difference } \\
\hline $\begin{array}{l}\text { Clusters in the countries } \\
\text { of innovation followers }\end{array}$ & 17 & 51.65 & \multirow{3}{*}{ p-value } & \multirow{3}{*}{0.006} \\
\hline $\begin{array}{l}\text { Clusters in the countries } \\
\text { of moderate innovators }\end{array}$ & 63 & 37.49 & & \\
\hline Total & 80 & & & \\
\hline \multicolumn{5}{|c|}{$0.006<0.00833 \mathrm{H}_{0}$ is rejected: significant difference } \\
\hline
\end{tabular}
in annual cluster budgets in various groups of countries 
End of Table 2

\begin{tabular}{|c|c|c|c|c|}
\hline $\begin{array}{c}\text { Division of clusters according } \\
\text { to the innovation performance } \\
\text { of the countries where these } \\
\text { clusters exist }\end{array}$ & $\begin{array}{l}\text { Number } \\
\text { of clusters }\end{array}$ & $\begin{array}{l}\text { Average } \\
\text { rank }\end{array}$ & \multicolumn{2}{|c|}{$\begin{array}{l}\text { Minimum level of } \\
\text { significance for the } \\
\text { rejection of the null } \\
\text { hypothesis }\end{array}$} \\
\hline $\begin{array}{l}\text { Clusters in the countries } \\
\text { of innovation followers }\end{array}$ & 17 & 17.82 & \multirow{3}{*}{$\mathrm{p}$-value } & \multirow{3}{*}{0.007} \\
\hline $\begin{array}{l}\text { Clusters in the countries } \\
\text { of the modest innovators }\end{array}$ & 11 & 9.64 & & \\
\hline Total & 28 & & & \\
\hline \multicolumn{5}{|c|}{$0.007<0.00833 \mathrm{H}_{0}$ is rejected: significant difference } \\
\hline $\begin{array}{l}\text { Clusters in the countries } \\
\text { of moderate innovators }\end{array}$ & 63 & 38.40 & \multirow{3}{*}{ p-value } & \multirow{3}{*}{0.254} \\
\hline $\begin{array}{l}\text { Clusters in the countries } \\
\text { of the modest innovators }\end{array}$ & 11 & 32.36 & & \\
\hline Total & 74 & & & \\
\hline \multicolumn{5}{|c|}{$0.254>0.00833 \mathrm{H}_{0}$ is not rejected } \\
\hline
\end{tabular}

Source: Self-processed based on the IBM SPSS Statistics outputs.

Pair comparisons of shares of central government subsidies have confirmed that clusters in the countries of innovation leaders and innovation followers, i.e. the clusters in the countries with higher levels of innovation performance gain statistically significantly larger shares of national funds than the clusters in the countries of moderate and modest innovators, i.e. the clusters in the countries with lower levels of innovative performance. The greatest share of funds at the national level comes to the budgets of the clusters in the countries of innovation leaders. The clusters in the countries of innovation followers also greatly use the funds allocated in the form of state subsidies. On the other hand, the clusters in the countries of moderate and modest innovators only rarely benefit from such funds. This is frequently reflected in their lower competitiveness.

\section{Mann-Whitney tests with Bonferroni correction}

$$
\begin{aligned}
& \mathrm{H}_{0}: \mu_{1}=\mu_{2} \quad \mathrm{H}_{0}: \mu_{1}=\mu_{3} \quad \mathrm{H}_{0}: \mu_{1}=\mu_{4} \quad \mathrm{H}_{0}: \mu_{2}=\mu_{3} \quad \mathrm{H}_{0}: \mu_{2}=\mu_{4} \quad \mathrm{H}_{0}: \mu_{3}=\mu_{4} \\
& \mathrm{H}_{1}: \mu_{1} \neq \mu_{2} \quad \mathrm{H}_{1}: \mu_{1} \neq \mu_{3} \quad \mathrm{H}_{1}: \mu_{1} \neq \mu_{4} \quad \mathrm{H}_{1}: \mu_{2} \neq \mu_{3} \quad \mathrm{H}_{1}: \mu_{2} \neq \mu_{4} \quad \mathrm{H}_{1}: \mu_{3} \neq \mu_{4}
\end{aligned}
$$

Discrepancies between the groups of clusters in pair comparisons of shares of subsidies from regional levels are not as large as those at the national level. Despite this, it is mainly the clusters in the countries of innovation followers that have high shares of funds from the regional levels. On the contrary, the clusters in the countries with lower levels of innovation performance either do not benefit from regional subsidies at all (the clusters in the countries of the modest innovators) or receive only very negligible amounts of funds from regional levels (the clusters in the countries of moderate innovators). No statistically significant differences were recorded in comparisons of shares of regional self-government subsidies in the cluster budgets in the countries of innova- 
Table 3. Pair comparisons of shares of regional self-government subsidies in cluster budgets in various groups of countries

\begin{tabular}{|c|c|c|c|c|}
\hline $\begin{array}{c}\text { Division of clusters according } \\
\text { to the innovation performance } \\
\text { of the countries where these } \\
\text { clusters exist }\end{array}$ & $\begin{array}{l}\text { Number of } \\
\text { clusters }\end{array}$ & $\begin{array}{l}\text { Average } \\
\text { rank }\end{array}$ & \multicolumn{2}{|c|}{$\begin{array}{l}\text { Minimum level of } \\
\text { significance for the } \\
\text { rejection of the null } \\
\text { hypothesis }\end{array}$} \\
\hline $\begin{array}{l}\text { Clusters in the countries } \\
\text { of innovation leaders }\end{array}$ & 34 & 22.79 & \multirow{3}{*}{ p-value } & \multirow{3}{*}{0.013} \\
\hline $\begin{array}{l}\text { Clusters in the countries } \\
\text { of innovation followers }\end{array}$ & 17 & 32.41 & & \\
\hline Total & 51 & & & \\
\hline \multicolumn{5}{|c|}{$0.013>0.00833 \mathrm{H}_{0}$ is not rejected } \\
\hline $\begin{array}{l}\text { Clusters in the countries } \\
\text { of innovation leaders }\end{array}$ & 34 & 49.82 & \multirow{3}{*}{ p-value } & \multirow{3}{*}{0.894} \\
\hline $\begin{array}{l}\text { Clusters in the countries } \\
\text { of moderate innovators }\end{array}$ & 63 & 47.68 & & \\
\hline Total & 97 & & & \\
\hline \multicolumn{5}{|c|}{$0.894>0.00833 \mathrm{H}_{0}$ is not rejected } \\
\hline $\begin{array}{l}\text { Clusters in the countries } \\
\text { of innovation leaders }\end{array}$ & 34 & 24.46 & \multirow{3}{*}{ p-value } & \multirow{3}{*}{0.061} \\
\hline $\begin{array}{l}\text { Clusters in the countries } \\
\text { of the modest innovators }\end{array}$ & 11 & 18.50 & & \\
\hline Total & 45 & & & \\
\hline \multicolumn{5}{|c|}{$0.061>0.00833 \mathrm{H}_{0}$ is not rejected } \\
\hline $\begin{array}{l}\text { Clusters in the countries } \\
\text { of innovation followers }\end{array}$ & 17 & 52.88 & \multirow{3}{*}{$\mathrm{p}$-value } & \multirow{3}{*}{0.004} \\
\hline $\begin{array}{l}\text { Clusters in the countries } \\
\text { of moderate innovators }\end{array}$ & 63 & 37.16 & & \\
\hline Total & 80 & & & \\
\hline \multicolumn{5}{|c|}{$0.004<0.00833 \mathrm{H}_{0}$ is rejected: significant difference } \\
\hline $\begin{array}{l}\text { Clusters in the countries } \\
\text { of innovation followers }\end{array}$ & 17 & 18.06 & \multirow{3}{*}{ p-value } & \multirow{3}{*}{0.001} \\
\hline $\begin{array}{l}\text { Clusters in the countries } \\
\text { of the modest innovators }\end{array}$ & 11 & 9.00 & & \\
\hline Total & 28 & & & \\
\hline \multicolumn{5}{|c|}{$0.001<0.00833 \mathrm{H}_{0}$ is rejected: significant difference } \\
\hline $\begin{array}{l}\text { Clusters in the countries } \\
\text { of moderate innovators }\end{array}$ & 63 & 39.07 & \multirow{3}{*}{ p-value } & \multirow{3}{*}{0.045} \\
\hline $\begin{array}{l}\text { Clusters in the countries of the } \\
\text { modest innovators }\end{array}$ & 11 & 28.50 & & \\
\hline Total & 74 & & & \\
\hline \multicolumn{5}{|c|}{$0.045>0.00833 \mathrm{H}_{0}$ is not rejected } \\
\hline
\end{tabular}

Source: Self-processed based on the IBM SPSS Statistics outputs. 
tion leaders and the countries of the moderate and modest innovators. Nevertheless, statistically significant differences were observed in comparisons of shares of regional self-government subsidies among the clusters in the countries of innovation followers and the countries of the moderate and modest innovators.

\section{Assessment of the proposed hypotheses}

Hypothesis No. 1 is assuming greater shares of state and regional subsidies allocated to clusters in the countries with higher levels of innovation performance and this hypothesis is found to be true.

When comparing the shares of central government subsidies in annual cluster budgets between the clusters in the countries of innovation leaders and innovation followers, and the clusters in the countries of the moderate and modest innovators, statistically significant differences were indicated in all four mutual pair comparisons in the relevant indicator.

In the examination of shares of regional self-government subsidies in cluster budgets, smaller differences were detected among the individual groups of clusters than in the previous case. Equally (as in the shares of national subsidies), statistically significant differences were found among the clusters in the countries of innovation followers and the countries of the moderate and modest innovators. There were no statistically significant differences among the clusters in the countries of innovation leaders and the clusters in the countries of the moderate and modest innovators in regional subsidies. Despite this, it may be concluded that Hypothesis No. 1 is plausible. The hypothesis clarifies the mutual relation between the innovation performance and financing clusters from the closer territorial level (regional, national). This can be explained by generally higher budgets of regional and national administration in the countries of innovation leaders and more developed regional innovation systems. Also, closer management of financial support usually means better knowledge of context, monitoring and cluster performance supporting the devolutionist principle of subsidiarity.

On the contrary, Hypothesis No. 2 is shown only partially true. Although the clusters in the countries with lower levels of innovation performance use slightly greater amounts of finance from the Structural Funds and community programmes of the European Union than the clusters in the countries with higher levels of innovation performance, such differences are not statistically significant. This is because all groups of clusters, regardless of the innovation performance of the residing countries, obtain substantial (at least 30 percent) funding from the Structural Funds and community programmes of the European Union. The Structural Funds are considered as an additional source of financing, but in the less innovation performing countries this source is often exclusive for financing cluster activities, what makes the development of the clusters dependent on the actual EU settings of goals and not corresponding to cluster needs. The financial vulnerability is a high risk of a cluster survival. Low innovation performance goes hand in hand with a lack of accessible, flowing and well-tailored finance. 


\section{Conclusions}

The amount of financial support for clusters from public funds differs greatly in the European countries. While there are no statistically significant differences in the examined clusters in the countries with different levels of innovation performance in the exploitation of resources from the Structural Funds and community programmes of the EU, the clusters in the countries with higher levels of innovation performance receive funds in the form of central government and regional self-government subsidies more frequently than the clusters in the countries with lower levels of innovation performance. The main reason is that the clusters in the countries with lower levels of innovation performance face a complicated problem to receive subsidies and are forced to resort solely to collecting relatively high membership fees from the cluster members. As a result, the lack of the financial resources of subsidies prevents them from setting and fulfilling ambitious goals that could have a positive impact on the level of regional competitiveness. Moreover, limited resources may lead to problems with co-financing national or international projects. At the same time, higher membership fees in the clusters in the countries with lower innovation performance (resulting from the lack of subsidies) cause tensions within most clusters and increase pressure (particularly from the highest contributing companies) on their facilitators. A weak point of cluster financing in less innovative countries is not only a lack of finance, in general, but moreover a lack finance from regional or country public sources and too centralised financing, against the subsidiarity principle. In other words, the closer finance is supposed to be spent more efficiently.

The competitiveness of the clusters in the countries with a higher level of innovation performance, in the case they are partly subsidised, is high and bears out the appropriateness of cluster policies in these countries (Ketels 2013). The representatives at a national or regional level in Germany, Sweden, Switzerland, Austria or Denmark have come to a conclusion that providing subsidies to clusters is an appropriate manner of enhancing their competitiveness and thereby enhancing the competitiveness of municipalities or regions where clusters exist. There is a reason to assume that more generous funding to clusters in the less performing countries in innovation would be a sensible use of the public finances. Hence, the national or regional level in these countries would not run the risk of the public resources being mismanaged or wasted as some clusters in the countries with lower levels of innovation performance have repeatedly proved a certain level of their competitiveness even without the help of public funding, and without subsidies in particular. In conclusion, it can be expected that potential support for clusters could help both the clusters and the whole industry or region where they operate.

\section{References}

Andersson, T.; Schwaag-Serger, S.; Sörvik, J.; Wise Hansson, E. 2004. The cluster policies whitebook. International Organisation for Knowledge Economy and Enterprise Development, Malmö.

Barsoumian, S.; Severin, A.; van der Spek, T. 2011. Eco-innovation and national cluster policies in Europe - a qualitative review [online], [cited 30 April 2013]. Available from Internet: http:// www.clusterobservatory.eu/eco/uploaded/pdf/1315915223865.pdf 
Bialic-Davendra, M.; Pavelková, D. 2011. Clusters phenomenon from Polish perspective, International Journal of Education and Information Technologies 5(3): 301-309.

Borrás, S.; Tsagdis, D. 2008. Cluster policies in Europe: firms, institutions and governance. Cheltenham: Edward Elgar. http://dx.doi.org/10.4337/9781781007716

CLOE. 2006. Clusters linked over Europe. Cluster management guide - guidelines for the development and management of cluster initiatives [online], [cited 30 July 2013]. Available from Internet: http://www.clusterforum.org

European Commission. 2013. Innovation union scoreboard 2013. Brussels.

Ginevičius, R.; Podvezko, V. 2009. Evaluating the changes in economic and social development of Lithuanian Counties by multiple criteria methods, Technological and Economic Development of Economy 15(3): 418-436. http://dx.doi.org/10.3846/1392-8619.2009.15.418-436

Hudec, O.; Sisáková, J.; Tartal’ová, A.; Želinský, T. 2007. Štatistické metódy v ekonomických vedách [Statistical Methods in Economics]. Košice: Technical University in Košice.

Kaklauskas, A.; Zavadskas, E. K.; Šaparauskas, J. 2009. Conceptual modelling of sustainable Vilnius development, Technological and Economic Development of Economy (15)1: 154-177. http://dx.doi.org/10.3846/1392-8619.2009.15.154-177

Ketels, C. 2013. Recent research on competitiveness and clusters: what are the implications for regional policy?, Cambridge Journal of Regions, Economy and Society (6)2: 269-284.

http://dx.doi.org/10.1093/cjres/rst008

Ketels, C. 2015. Competitiveness and clusters: implications for a new European growth strategy, Working Paper No. 84 [online], [cited 18 November 2015]. Available from Internet: http://www. hbs.edu/faculty/Pages/item.aspx?num $=49627$

Ketels, C.; Lindqvist, G.; Sölvell, Ö. 2006. Cluster initiatives in developing and transition economies. Center for Strategy and Competitiveness: Stockholm.

Lindqvist, G.; Sölvell, Ö. 2011. Clusnet final report-organising clusters for innovation: lessons from city regions in Europe. Stockholm, Clusnet.

Meier zu Köcker, G. 2009. Clusters in Germany - an empirical based insight view on emergence, financing, management and competitiveness of the most innovative clusters in Germany. Institute for Innovation and Technology, Berlin.

Ministry of Economy of the Slovak Republic. 2011. Návrh Inovačnej politiky na roky 2011 až 2013 [The Innovation Policy of the Slovak Republic for 2011 to 2013]. Bratislava.

Ministry of Industry and Commerce of the Czech Republic. 2010. Operačni program podnikánía inovace 2007-2013 [Operational programme enterprise and innovation for the years 2007-2013]. Prague.

Monroe, S. A. 2006. How corporate strategy contributes to firm performance: a cross-sectional study of resource governance decision making in US firms: doctoral thesis. Massey University, Palmerston North, New Zealand.

OECD. 2007. Competitive regional clusters - national policy approaches [online], [cited 29 April 2013]. Available from Internet: http://www.oecd-ilibrary.org/urban-rural-and-regional-development/competitive-regional-clusters_9789264031838-en

Oxford Research AS. 2008. Cluster policy in Europe - a brief summary of cluster policies in 31 European countries. Kristiansand, Norway.

Pavelková, D.; Friedel, L.; Jirčíková, E.; Knápková, A.; Skokan, K.; Škodáková, P. 2009. Klastry a jejich vliv na výkonnost firem [Clusters and their influence on company performance]. Prague: Grada.

Raines, P. 2001. Local or national competitive advantage? The tensions in cluster development policy, Regional and Industrial Policy Research Paper No. 43. European Policies Research Centre, University of Strathclyde, Glasgow. 
Rothgang, M.; Cantner, U.; Dehio, J.; Engel, D. 2015. Accompanying evaluation of the funding instrument "Spitzencluster-Wettbewerb" (Leading-Edge Cluster Competition) of the Federal Ministry of Education and Research. RWI Materialien, No. 90.

Sheskin, D. J. 2007. Handbook of parametric and nonparametric statistical procedures. Chapman and Hall/CRC.

Skokan, K.; Zotykova, L. 2014. Evaluation of business cluster performance during its lifecycle, Acta Universitatis Agriculturae et Silviculturae Mendelianae Brunensis 62(6): 1395-1405. http://dx.doi.org/10.11118/actaun201462061395

Sölvell, Ö. 2009. Clusters - balancing evolutionary and constructive forces [online], [cited 26 March 2013]. Available from Internet: http://www.cluster-research.org/redbook.htm

Sölvell, Ö.; Ketels, C.; Lindqvist, G. 2003. The cluster initiative greenbook [online], [cited 25 March 2013]. Available from Internet: http://www.enterprise-development.org/page/ download?id=1773

Urbančíková, N.; Burger, P. 2010. Miera regionalizácie inovačných politík a jej vplyv na inovačnú výkonnost' regiónov [The level of regionalization of innovation policies and their impact on innovation performance of regions], E\&M Ekonomie a Management (13)1: 23-36.

Uyarra, E.; Ramlogan, R. 2012. The effects of cluster policy on innovation. Nesta working paper No. $12 / 05$.

Nataša URBANČÍKOVÁ is assoc. professor at the Technical University of Kosice, Faculty of Economics. She is Head of Department of Regional Science and Management. Her research is focused on innovation, clusters and HRD.

Peter BURGER is an assistant professor at the Technical University of Kosice, the Faculty of Economics. His research is focused on innovation (innovation processes, innovation funding from public and private funds) and clusters (evaluation of the cluster's performance, identification of clusters, clusters funding). 